\title{
РОЛЬ МАТЕРІАЛЬНО-ТЕХНІЧНОЇ БАЗИ ТА НАУКОВО- ПЕДАГОГІЧНОГО ЗАБЕЗПЕЧЕННЯ В ПІДГОТОВЦІ ЛІКАРЯ МАЙБУТНЬОГО (СІМЕЙНОГО ЛІКАРЯ)
}

\author{
І. В. Шишка, А. В. Кудієвський \\ КУ “Запорізька обласна клінічна лікарня” ЗОР, \\ Запорізький державний медичний університет
}

\section{THE ROLE OF MATERIAL AND TECHNICAL BASE OF SCIENTIFIC AND PEDAGOGICAL SUPPORT IN TRAINING OF THE FUTURE DOCTOR (FAMILY DOCTOR)}

\author{
I. V. Shyshka, A. V. Kudiyevskyi \\ Zaporizhian Regional Clinical Hospital, \\ Zaporizhian State Medical University
}

\begin{abstract}
Мета роботи - обгрунтувати роль та значення матеріально-технічної бази та науково-педагогічного забезпечення в підготовці лікаря майбутнього. Взаємопорозуміння керівників вищих навчальних закладів (Академії післядипломної підготовки лікарів та Медичного університету) з адміністрацією баз практики, охорони здоров'я в залученні сучасних методів дослідження та апаратури для всебічної підготовки лікаря майбутнього.

У статті представлено світогляд випускників вузу, інтернів та клінічних ординаторів на систему підготовки сімейного лікаря в цілому на перспективу сімейної медицини.

The aim of the work - to justify the role and value of material and technical base of scientific and pedagogical support in the training of the future doctor; ensure understanding of heads of higher educational institutions (Academy of Post-graduate Education and the Medical University) with the administration of the practice bases, with the health administration in the introduction of modern methods of research and equipment for the comprehensive training of future doctors.

The papers filed outlook graduates, interns and medical residents in the family doctor system of training and generally the future of family medicine.
\end{abstract}

Вступ. За останні кілька десятиліть у структурі амбулаторно-поліклінічної ланки пріоритетного розвитку набувала спеціалізована медична допомога, що певною мірою стримувало розвиток первинної медико-санітарної допомоги (ПМСД), особливо на рівні організації роботи дільничного терапевта. Внаслідок цього поступово відбувалася передача в компетенцію інших спеціалістів багатьох оздоровчих, профілактичних, лікувально-діагностичних функцій та лікувальних маніпуляцій, які складають його базову підготовку, відносяться до об'єму первинної лікарської допомоги, що надається при дитячих та хірургічних хворобах, вагітності, пологах, жіночих захворюваннях, захворюваннях нервової системи, очей, вуха, горла та носа, дерматологічних захворюваннях, при професійній патології, онкологічних, психічних та інших захворюваннях $[1,2]$.

\footnotetext{
( I. В. Шишка, А. В. Кудієвський
}

Внаслідок цього поступово скоротився об’єм медичної допомоги, що надається населенню дільничним терапевтом, певною мірою зменшилась його відповідальність за здоров’я пацієнта. Престиж дільничного терапевта серед населення та медичних працівників поступово знизився, його конкурентоспроможність в сучасних умовах також знизилась, а поширеною точкою зору стало усвідомлення, що до дільничного терапевта треба йти тільки за лікарняним. Поступово сформувалося усвідомлення, що звернення пацієнта до дільничного терапевта не завжди є ефективним, але і звернення до “вузьких" спеціалістів не набрало регулярності, поширеності і стало епізодичним [3, 4].

Добре відомо, що у світі ще не існує всеосяжної та універсальної, ідеальної системи охорони здоров’я, але слід констатувати, що в Україні на сьогодні сформувалося соціальне замовлення су- 
спільства на створення в структурі первинної ланки охорони здоров’я лікаря особливої категорії, який би міг відігравати роль авторитетного професіонала на первинному рівні, який би задовольняв медичні потреби широкого діапазону, тобто сімейного лікаря.

В Україні сімейна медицина, як спеціальність, була визнана на початку 90-х. За 10 років ставлення населення країни і медичних працівників до лікарів загальної практики змінилося на краще. Сімейні лікарі заявили про себе організацією приватної практики, власних кафедр при університетах.

Значні успіхи в галузі медицини були досягнуті завдяки поглибленню наукових знань і спеціалізації практичної медицини. Однак поглиблення наукових уявлень щодо причин та механізмів розвитку захворювання саме по собі не допомагає конкретному пацієнту. Охорона здоров’я, як система збереження і поліпшення здоров'я людей, опинилася перед небезпекою втрати гуманістичних основ медицини, оскільки в умовах поширеного обгрунтованого усвідомлення населенням ефективності підвищення вузької спеціалізації медичної допомоги у потенціального пацієнта поступово наростає відчуття безпорадності на етапі необхідності первинного звернення за наданням медичної допомоги [5-7].

У зв’язку з цим виникла необхідність у формуванні якісно нової схеми надання ПМСД населенню та якісно нового спеціаліста - лікаря загальної практики, або сімейного лікаря, повноваженнями якого було б вирішення більшості медичних питань одночасно із наданням кваліфікованих рекомендацій з питань соціальної, правової, профілактичної і реабілітаційної допомоги [8].

Сімейний лікар частіше за інших спеціалістів має використовувати раціональну як з медичної, так і з економічної точки зору обгрунтовану тактику по відношенню до необхідних лабораторних та інструментальних методів дослідження і рекомендувати необхідність застосування спеціалізованих технологій лікування.

Основна частина. Для написання цієї статті нами проведений аналіз анкет і рефератів випускного курсу інтернів та клінічних ординаторів кафедр післядипломної підготовки як Академії 3МАПО, так і Запорізького державного медичного університету. Анкети в кількості 116, реферати - 90.

В анкетах і рефератах основними питаннями було:

1. Перспективи сімейної медицини в Україні.

2. Проблеми в підготовці сімейного лікаря.
3. Чи приваблює Вас перспектива сімейного лікаря?

Використані паспортні дані обласної клінічної лікарні і штати, кількість відділень та їх оснащення, кількість кафедр, на яких проводиться підготовка студентів та майбутніх сімейних лікарів.

Кадровий потенціал лікарського складу комунальної установи "Запорізька обласна клінічна лікарня” Запорізької обласної ради

Лікарі - 285 фізичних осіб + 20 лікарів-інтернів на бюджетній основі +50 лікарів-інтернів за цивільно-правовим договором = 355 осіб.

165 осіб мають вищу кваліфікаційну категорію, що складає 58 \%, 36 осіб - першу категорію, що складає 13 \%, 26 осіб - другу категорію, що складає 9 \%.

Ступінь доктора медичних наук мають 2 особи, які $є$ керівниками медичних підрозділів лікарні. 32 лікарі мають ступінь кандидата медичних наук. 13 завідувачів структурних підрозділів установи мають ступінь кандидата медичних наук.

База стажування для підготовки лікарів-інтернів за 10 спеціальностями: “Анестезіологія та реаніматологія”, “Хірургія”, “Лабораторна діагностика”, “Урологія”, “Отоларингологія”, “Офтальмологія”, “Внутрішні хвороби”, “Радіологія”, “Ортопедія і травматологія”, “Неврологія”.

Керівники лікарів-інтернів в 100 відсотках випадків мають вищу кваліфікаційну категорію 3 відповідної спеціальності, 2 з них зі ступенем доктора медичних наук, 6 зі ступенем кандидата медичних наук.

Основна сучасна апаратура, що використовується у лікувальній практиці і навчальному процесі, придбана за кошти ОКЛ, Медичної академії післядипломної підготовки та Запорізького державного медичного університету:

- аналізатор газів крові NPT 7;

- аналізатор мікробіологічних VITEK 2 Compact 15;

- апарат для гемодіалізу 4008 H “Prometheus”;

- апарат для гемодіалізу 5008S ONLINEplus;

- апарат УЗД “ТOSHIBA”;

- відеоендоскопічна система з відеогастроскопом 2500 серії;

- відеоендоскопічна стійка для лапароскопічних операцій;

- лапароскопічна стійка з набором інструментів;

- лапароскопічне обладнання Linvatek;

- лікувальний комплекс “УРАТ-П” № 45;

- медичний комплекс “Простатрон”;

- мікроскоп операційний офтальмологічний ОМ - 8; 
- система магнітно-резонансної діагностики I Open 0,36T;

- сканер діагностичний ультразвуковий ЕН ВИЗОР;

- сканер ультразвуковий діагностичний Voluson 730 Pro;

- ультразвукова діагностична система ACUSON X300.

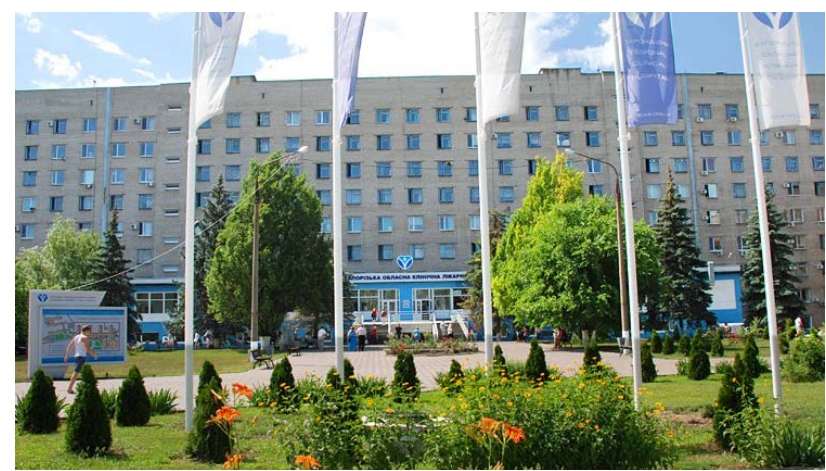

Рис. 1. Загальний вигляд Запорізької обласної клінічної багатопрофільної лікарні.

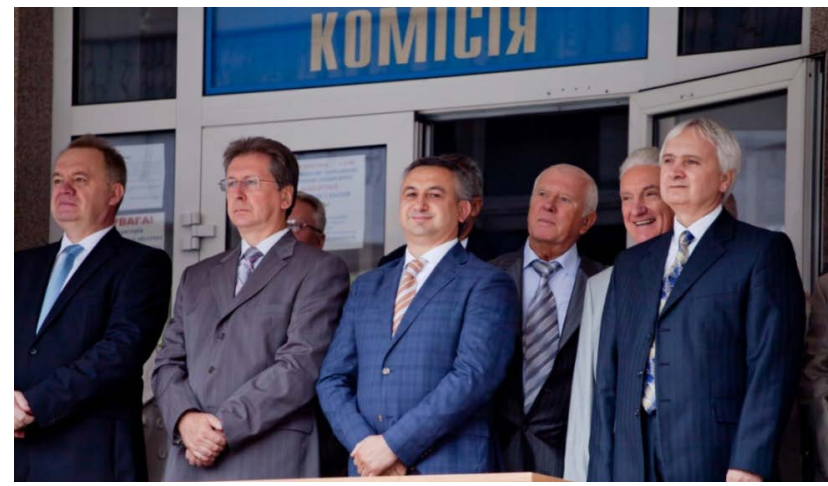

Рис. 2. Ректор ЗДМУ разом з його заступниками з навчальної, наукової та лікувальної роботи після підписання контракту про сумісну роботу по оптимізації процесу підготовки випускників медичного вузу на післядипломних етапах.

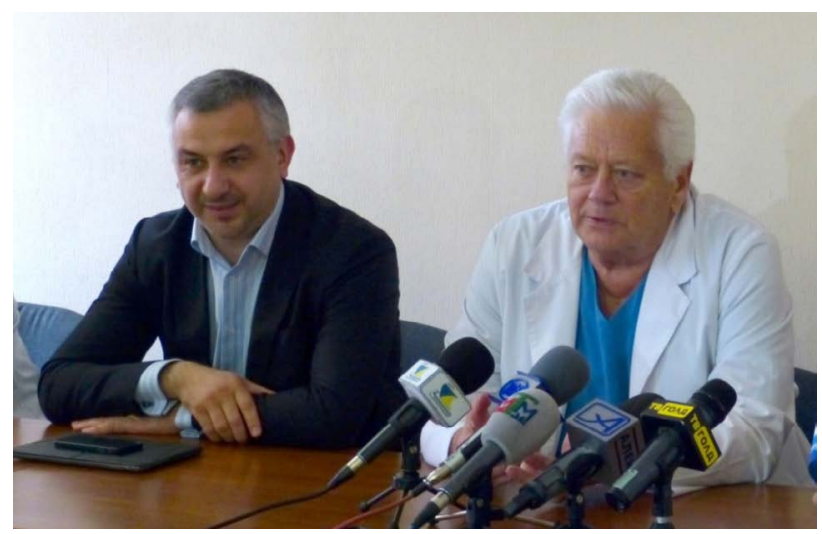

Рис. 3. Ректор Запорізької академії післядипломної підготовки лікарів, головний лікар КУ “Запорізька обласна клінічна лікарня” ЗОР на прес-конференції по взаємодії науки та практики в підготовці фахівців сімейної медицини.

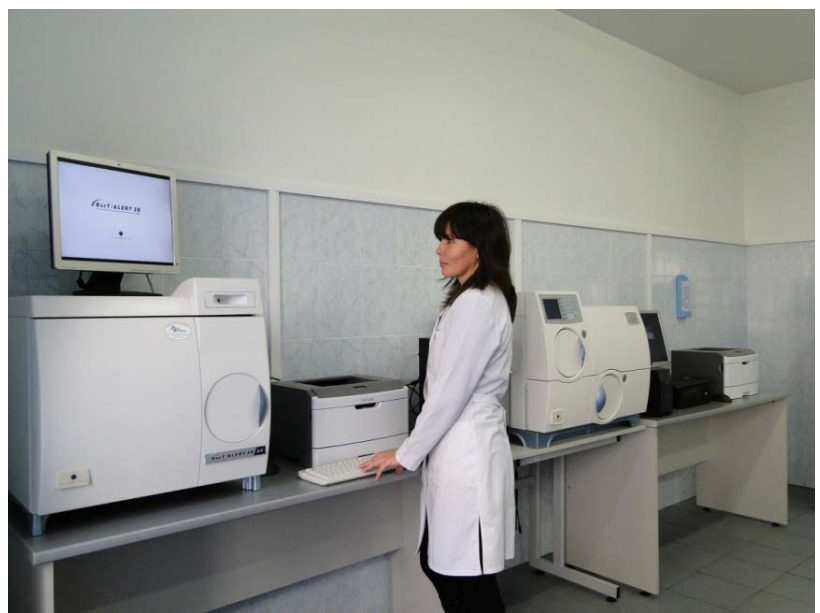

Рис. 4. Використання мікробіологічного аналізатора Vitek 2 Compact 25.

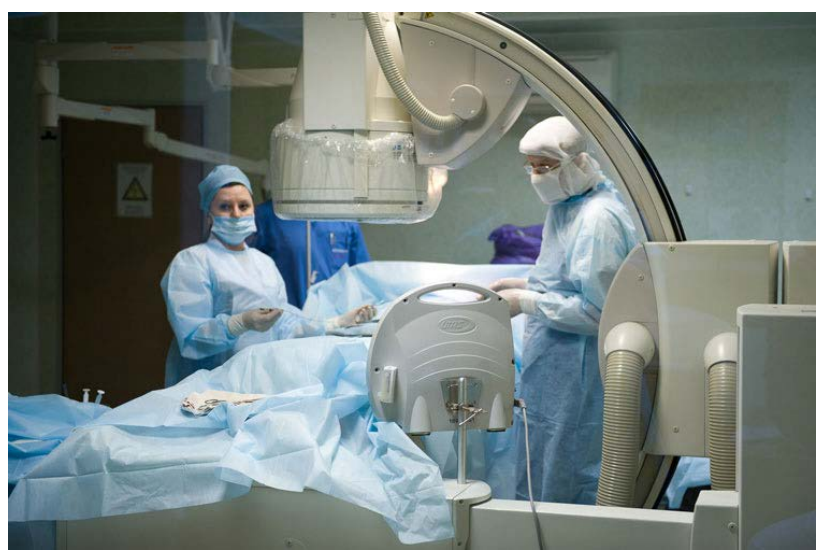

Рис. 5. Метод ангіографії з використанням сучасної апаратури.

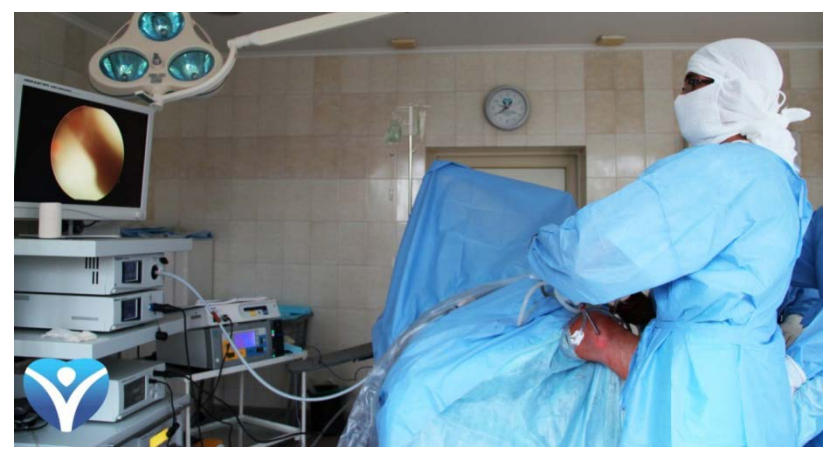

Рис. 6. Артроскопічні втручання на суглобах кінцівок.

На наш погляд, для формування лікаря майбутнього необхідно мати як бази сучасного матеріально-технічного забезпечення, так і штати фахівців вищої професіональної як практичної, так і наукової підготовки, щоб сімейний лікар не став прообразом “земського”.

На основі рефератів та анкет інтернів, клінічних ординаторів та студентів-випускників, 90 \% респондентів вказують на велике значення матеріально-технічної бази клінік та стану науково- 


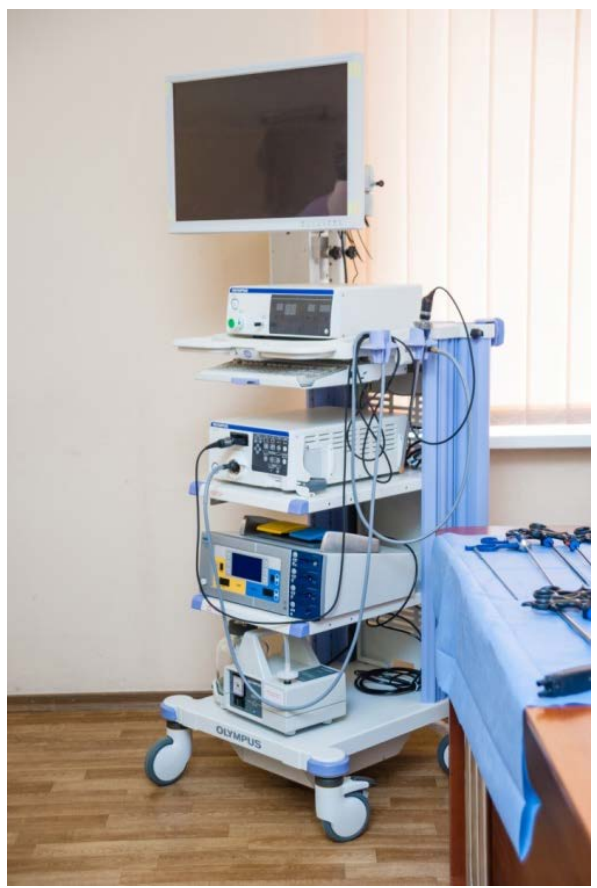

Рис. 7. Лапароскопічна стійка.

педагогічних кадрів у підготовці лікарів сучасності і сімейного лікаря зокрема.

Широкі і глибокі знання сучасних методів діагностики і лікування будуть основними відмінними рисами сімейного лікаря від земського.

Всі респонденти вказали на те, що сімейному лікарю в найближчій перспективі необхідно мати сучасне інформаційне забезпечення (комп’ютер)

\section{Список літератури}

1. Васильєва Л. В. Практична підготовка студентів 6 курсу на клінічних базах / Л. В. Васильєва // Матеріали Х ювілейної Всеукр. навч.-наук. конф. $з$ міжнар. участю. Тернопіль, 2013. - 58 с.

2. Формування профілактичного мислення як один із аспектів належної підготовки майбутніх лікарів / [Л. І. Власик, О. М. Жуковський, О. В. Кушнір та ін.]. Тернопіль, 2013. - 68 с.

3. Грандо А. А. Врачебная этика и медицинская деонтология / А. А. Грандо. - К., 1988. - 186 с.

4. Наскрізна програма підготовки студентів медичних факультетів вищих медичних навчальних закладів IV рівня акредитації та лікарів-інтернів для оволодіння практичними навичками та методиками, необхідними для дистанційної консультації з ведучими вузькими спеціалістами та ведення комп’ютерного обліку документації; авто в індивідуальному користуванні.

Більшість респондентів - “контрактники”, майже всі не збираються їхати на роботу сімейним лікарем у сільські райони через низьку заробітну плату i відсутність там елементарних умов для проживання та відпочинку.

Висновки. Підсумовуючи вищезазначене, можна сформувати міри, які є необхідними для підготовки лікаря сучасності та взагалі формування сімейної медицини в Україні:

1. Мати сучасну матеріально-технічну базу у вищих навчальних закладах та базових клініках.

2. Взаємопорозуміння та співдружність керівників лікувально-практичних закладів з керівниками вузів.

3. Держава повинна переглянути концепцію сімейної медицини.

4. Витрати на підготовку сімейних лікарів треба розглядати як довгострокові інвестиції.

5. Підготовку сімейного лікаря проводити не тільки на післядипломному, але й на переддипломному етапі.

6. Для сімейних лікарів сільської місцевості виділити безкоштовно особистий транспорт та забезпечити засобами на мобільний зв’язок.

7. Спростити ведення медичної документації.

для роботи на посадах лікарів за спеціальністю “Загальна практика - сімейна медицина”. - К., 2011.

5. Ніколаєнко С. А. Якість української освіти - запорука інноваційного розвитку держави / С. А. Ніколаєнко // Нова педагогічна думка : наук.-метод. журн. 2012. - № 1. - 4 с.

6. Саух П. Синергія науки і освіти як головний ресурс суспільства знань. Євровиклики і українські проблеми / П. Саух // Нова педагогічна думка : наук.-метод. журн. 2012. - № 1.

7. Семейная медицина. - 2011. - № 4.- С. 114.

8. Стандарти і рекомендації щодо забезпечення якості в Європейському просторі вищої освіти. - К., 2012.

Отримано 12.05.16 